\title{
Translation Methods in the French Version of The Story of the Stone
}

\author{
YUAN Zhe \\ Wuhan Textile University, Wuhan, 430073, China \\ email: pauline_2005@163.com
}

Key word: French version; The Story of the Stone; Translation methods

\begin{abstract}
The Story of the Stone with 120 chapters, which was translated by Chinese-French translator Zhihua Li and his French wife Ya Ge together and proofread by the sinologist André d'Hormon, is the only French version so far. Based on it, French readers can appreciate this book after all, which has made great differences for the translation and spread of Chinese classics abroad. And this paper is aiming to discuss the embodiment of five methods to translate cross-cultural differences in this version, namely literal translation, conversion method, translation and annotation, paraphrase and transliteration.
\end{abstract}

\section{Introduction}

According to the book Culture and Translation written by Professor Jingyu Bai, in order to deal with the differences between two languages and cultures, different translation methods have to be used to reach the target of transferring two cultural information.[1] Combined with the translation methods concluded by professor Bai, how have these methods been represented in the French version of The Story of the Stone:

\section{Literal Translation}

Literal translation is a method that is most widely used. When literal translation is adopted, the independent linguistic units in the source language will be replaced by corresponding target language. [2] The combining form of these chosen target units will also close to that in source language as much as possible.

A. We know it is hard. But as a saying goes, "a thin dead camel is bigger than a horse"...... (Chapter Six)

Version: Nous connaissons aussi vos difficultés, répondit-elle. Seulement, comme le dit le proverbe, « un chameau mort de maigreur est encore plus grand qu'un cheval. [3]

This is a translation of Chinese proverb and each word, according to its meaning in source language, has its own corresponding word in target language. The combined meaning also meets the cognitive competence of target language readers, expresses the meaning of the source text fully and makes readers understand it more easily.

B. Yuan Yang says, “ nowadays people all make the cap to fit the head. Nothing can be wasted!” (Chapter Seventy-five)

Version: A cette heure, expliquala camériste Couple de Sarcelles, on fait ici à chacun son bonnet strictement à la mesure de sa tête, Impossible d'obtenir le moindre supplément.

" Make the cap to fit the head" is a Chinese proverb, referring that the size is suitable without increase or decrease. The version adopted a French idiom "faire son bonnet à la mesure de sa tête" to transform it literally, corresponding to source language and expressed the idea directly helping French readers understand it. 


\section{Conversion Method}

Different nations have different cognition to even the same thing due to different historic cultures, life regions, customs, religions and so on. Something has abundant connotation and denotation in one language and culture, leading to beautiful associations, but in another language is just ordinary without any cultural meaning. [4]

\section{A. Grandma Liu said, “......Man proposes, heaven disposes ......” (Chapter Six)}

The translator replaced dieu (god) into ciel (heaven) in the French proverb "I'homme propose et dieu dispose", which not only makes French readers understand, but correctly conveys Chinese deities culture that is different from western christian culture.

B. Feng said, “ The elderly lady is so good at taking care of people that she is like scirpus, so is it anyone's fault to be into the girl?” (Chapter Forty-six)

Version: Grande Soeur Phénix:” Vous avez si bienélevécete petite,que la voilà aussi svelte qu'un brin de jonc. Faut-il en vouloir aux gens qui veulent vous la prendre?

In this sentence, the translator didn't translate the word "scirpus" into ciboule (green onion) since this word just reminds French readers of a kind of material for cooking, which is without any sense of beauty. Instead, jonc (reed) was employed, which is also a plant growing in water but give people a sense of slender beauty due to its long and straight body. In this way, the author's meaning can be expressed and felt by readers.

\section{Translation and Annotation}

Some historic events, characters and stories in original version are often given certain cultural implications. [5] Translators will translate them literally at first, and then on such basis adopt some methods like addition and annotation to explain or state the cultural background. [6] This method not only can reserve the original culture color, but help readers understand the book. The method of translation and annotation has two common forms as well, addition and annotation.

\section{A. Addition. For example:}

1) Conscienceless. Bite the hand that feeds you. (Chapter Twenty-five)

Version: Méchant garçon! Semblable au chien qui voulait mordre l'immortel lü Dongbin, vous ignorez le coeur qui vous veut du bien !

The name Dongbin Lv is Chinese characteristic word, who is a member of “ Eight Gods". If it appears without any consideration, French readers will not know its meaning, so the translator added l'immortel (immortal) to explain his identity to avoid readers' puzzlement.

2) (Feng)......Could it be said that only brother Bao can replace you to stay in Mount Wutai in the future? (Chapter Twenty-two)

Version: ...Faut-il croire qu'il n’y aura, plus tard, que le seul frérot Jade pour conduire au Mont sacré des Cinq Terrasses votre auguste dépouille ?

If the Mount Wutai in this sentence was translated literally, it would make French readers confused. Mount Wutai is not just a ordinary mountain because it has a lot of connection to Chinese religion culture. It is a famous Buddhist mountain, and where it appears will give people associations about religion. Therefore, translator did not translate it literally but add the word sacré (sacred, religious), which presented the religious implication of Mount Wutai and met the aim of conveying cultural information. 
B. Annotation. For example:

1) In spite of the beautiful natural scene and the good time, I nevertheless have no mood to enjoy it. (Chapter Forty)

Version: Un si beau jour, un si beau paysage, Mais pourquoi, Ciel, un tel souci ?

The translator added annotation Citation du kiosque aux pivoines, ouvrage interdit aux jeunes fille.(Excerpt from Peony Pavilion. Banned book for women). This place echoes Lines from "The Western Chamber" Are Quoted in Fun, A Song from "Peony Pavilion" Distresses a Tender Heart (Chapter Twenty-three) and The Lady of the Alpinia Warns Against Dubious Tastes in Literature, The Queen of Bamboos' Quips Add to the General Enjoyment (Chapter Forty-two). Without annotation, readers would not know what brought subsequent development and connected the context, resulting in comprehension difficulties.

2) (Qing Wen) saw them two and said with cod face, “Oh! You haven’t drank cross-cupped wine yet but have already combed a bun!” (Chapter Twenty)

Version: A cette vue, elle émit un petit rire froid et s’écria :“Oh !Avant même l'échange des tasses nuptiales, vous voilà déjà au rite de coiffure!

"Cross-cupped wine" refers to a ritual during the Chinese ancient wedding custom: at the wedding night, the bride and bridegroom need to drink cross-cupped wine. [7] "Comb a bun" is also a ritual in the Chinese ancient wedding: referring that the second day after wedding, the lady would be combed a bun by her husband, indicating saying goodbye to the identity of a girl and becoming a woman. Qing Wen played a joke on purpose here when she saw Bao Yu was combing hair for She Yue. [8] After translating literally, the translator added an annotation (Note: L'échange des tasses nuptiales s'accomplit le soir du marriage, dans l'alcôve et sur la couche de noces.Le lendemain matin, l'époux aide la nouvelle épouse prendre coiffure de femme.) in order to help readers understand original text and know Chinese unique custom.

\section{Paraphrase}

On many cases, because of the great differences of expression and culture background in two languages, there is no corresponding word in target language to express the culture color of the word in source language, and annotation and conversion can't convey its cultural meaning neither. Then paraphrase can only be adopted. The so-called paraphrase refers that without the expression and literal meaning of the source language, the "equal" words in the target language are used to express the cultural information of the source language. For example:

A. Fang Guan, “ you are my grandma’s sister and can’t scold me. You don’t buy me. Mei Xiang---are all servants.” (Chapter Sixty)

Version: Ça ne vaut donc guère la peine, Madame la Concubine, de m'accabler de tant d'injures. D’ailleurs, je ne suis nullement une servant achetée par vous. Comme dit le proverbe: "La soeur jurée d'une servante ne peut être autre chose qu'une esclave.”

The translation of the last sentence is sworn sisters of a servant are also servants. "Mei Xaing" is a synonym of Chinese ancient lady's maid and servant girl. It means the sworn sisters of servants are all same servants. The translator adopted paraphrase and gave up "Mei Xaing”, the name with special meaning in original text, and replaced it by une servante (person who serve people), which avoided readers' misunderstanding. Such a way has translated its pragmatic meaning and also spread language and culture. 
B. His grandma got sick and he again became a sweet steamed bun and is hard to get. (Chapter Sixty)

Version: Cette petite-là, depuis que sa maîtresse est malade, c’est comme du nanan ; tout le monde se la dispute, et il n'y a plus moyen de mettre la main dessus.

The "steamed bun" in text is a kind of flour-made food in northern China. There is no such food in France so there is no equal word. The translator chose the word nanan, which means "sweet candy" originally and often refers to "delicious food". It is something French are familiar with and presents the connotation ans denotation of "steamed bun" as well.

\section{Transliteration}

Some specific images in source language are "blank" or "vacant” in target language. At this time, transliteration can only be used to transplant those images in target language. [9] This method not only can reserve the "exotic sense" in source language, but can take in borrowed words enriching target language and culture.

Li's version of The Story of the Stone used many paraphrases and little transliteration, most of which appear in the last names of the characters in book. According to the introduction in the book Translation Affairs in Lyon by Mr. Li, when he started to translate he Story of the Stone, he also adopted transliteration to translate the first names, but the proofreader Mr. André d'Hormon insisted on paraphrase. They discussed on this for a long time and finally Mr. Li was persuaded to give up transliterating first names and change into paraphrase, only remaining the transliteration of last names.

\section{Conclusion}

Such examples in the version are too numerous to mention one by one, and this paper according to each category just selected some representative examples. This shows that Li's version of The Story of the Stone has used several translation methods simultaneously. Selecting appropriate translation methods in different situations is worthy of our reference and study.

\section{References}

[1] Li,T.\&J.Alézas.1981.Le Rêve dans le Pavilon Rouge [M].Paris:Galimard. (Li,T.\&J.Alézas.1981.Le Rêve dans le Pavilon Rouge [M].Paris:Galimard.)

[2] Jingyu Bai. Culture and Translation [M]. Beijing: China Social Sciences Press, 2014.

[3] Xueqin Cao. The Story of the Stone (Pingbo Yu proofread, Qi Gong annotated)[M]. Beijing: People's Literature Press, 2002.

[4] Yumei Guo. Views on the Translation of Chinese Two-part Allegorical Sayings from the French Version of The Story of the Stone[J]. French Study. 2013.3.

[5] Yan Li. The "Deep Translation" of the French Version of The Story of the Stone and Its Cultural Transmission[J]. Foreign Language Teaching and Research. 2014.7.

[6] Shiwei Li. Primary Investigation on the Translation of the French Version of The Story of the Stone [J]. Journal of The Story of the Stone. 2013.3.

[7] Zhihua Li wrote, Li Jiang edited. Translation Affairs in Lyon [M]. The Commercial Press, 2005. P159.

[8] Xuqiang Mo. Study on the French Translation of Metaphors in The Story of the Stone[J]. Journal of Guangdong University of Foreign Studies. 2010.5.

[9] Bixian Zheng. The Fate of The Story of the Stone in France [M]. New Star Press, 2005.P141-146. 